\title{
Reflections on Indigenous commercial tobacco control: 'The dolphins will always take us home'
}

\author{
Raglan Maddox (D) , 1,2 Michelle Bovill,, ${ }^{3,4}$ Andrew Waa (D) , 5,6 Heather Gifford (D) , 7,8 \\ El-Shadan Tautolo (D) , 9,10 Patricia Nez Henderson (D) ,' ${ }^{11,12}$ Sydney Martinez, ${ }^{13,14}$ \\ Hershel Clark, ${ }^{11,12}$ Shane Bradbrook, ${ }^{15}$ Tom Calma ${ }^{16,17}$
}

For numbered affiliations see end of article.

\section{Correspondence to} Dr Raglan Maddox, Modewa Clan, Milne Bay, Papua New Guinea;

Raglan.Maddox@anu.edu.au
Commercial tobacco use is a complex behaviour influenced by a range of factors; most notable among Indigenous peoples is the impact of colonisation. ${ }^{12}$ The commodification of tobacco as a consumer product was commonly introduced by colonisers and has been used as a tool for coercive control through tobacco's addictive qualities. Colonisation causes trauma, stress, racism and exclusion from education and employment, which are all linked to commercial tobacco use. ${ }^{13-5}$ Across Turtle Island (North America), European colonisers appropriated, adulterated, modified, industrialised and commercialised tobacco as a commodity, in stark contrast to its use as a sacred medicine among many Indigenous peoples. ${ }^{6}$ Commercial tobacco was then brought through the Pacific as a sought-after commodity, providing a link to trade and the global economy. ${ }^{7}$ In Australia, commercial tobacco was provided in rations (payment in lieu of wages) until $1968 .^{8}$ Colonisation and its associated impacts have eroded Indigenous peoples' agency and broader self-determination at a community and population level. Mass production and distribution of commercial tobacco impedes Indigenous health, well-being and ways of knowing and doing. 6910

Understanding local Indigenous experiences and viewpoints of tobacco and coloniality provides alternative narratives that challenge colonialist ways of knowing, being and doing. Colonialist narratives have tended to focus on ill health and disadvantage, reproducing deficit discourse. ${ }^{11}$ Contextualising Indigenous commercial tobacco use within colonisation assists to address inaccurate notions that there is a biological basis for the use of commercial tobacco among Indigenous peoples, including fallacies $^{12}$ that Indigenous peoples are genetically predisposed to addiction. These are a form of deficit discourse based on and consistent with ideas and representation of Indigenous peoples as racially inferior and inhuman which have persisted since colonisation. ${ }^{13}$ It is important to recognise such contexts as the focus for tobacco control to empower Indigenous peoples to be free of commercial tobacco and nicotine dependence.

(c) Author(s) (or their employer(s)) 2022. No commercial re-use. See rights and permissions. Published by BMJ.

To cite: Maddox R, Bovill M, Waa A, et al. Tob Control 2022;31:348-351. and for future generations. As we reflect on tobacco control over 30 years, there is much to celebrate. We have witnessed examples of Indigenous excellence in commercial tobacco control as follows:

\section{Acknowledgement and increasing recognition of the true harms of colonisation}

This has been coupled with increasing and ongoing (re)vitalisation of sacred tobacco and the active tension with commercial tobacco use. ${ }^{691014}$ Colonisation is built on notions of racial superiority, leading to racist practices that began with genocide, cultural genocide and the betrayals of treaties and agreements with Indigenous peoples, some of whom have had a sacred relationship with tobacco for ceremony and rituals since time immemorial. ${ }^{469101516}$ From tobacco being held in the highest regard among some Indigenous peoples as a sacred plant or leaf used in special ceremonies, colonisers have manipulated and adulterated the tobacco plant into a highly commodified product and have used appropriated Indigenous imagery to sell these products. ${ }^{36917}$

\section{Growth of commercial tobacco control in Indigenous contexts}

The 1990 World Conference on Tobacco or Health held in Noongar Country (Perth, Australia) was among the first commercial tobacco control conferences to include an Indigenous (Aboriginal) Pre-Conference Workshop, reflecting the tireless work and leadership of Elders, Knowledge Keepers, communities and academics to generate awareness and recognise the importance of Indigenous tobacco control. This awareness has continued to grow; it is not uncommon to witness safer spaces for Indigenous peoples in commercial tobacco control journals, meetings and conferences. Aotearoa New Zealand held dedicated Indigenous tobacco control conferences in the late 1990s-2000s. On Turtle Island, the National Conference on Tobacco or Health and the National Tobacco Conference for Indigenous Peoples have supported Indigenous peoples. The Oceania Tobacco Control Conference (OTCC) has consistently hosted Indigenous streams and recognised Indigenous leadership since at least 2009. Further, in 2017 the OTCC fostered the Indigenous Peoples to the 2017 Oceania Tobacco Control Conference: Smoke Free Oceania statement ${ }^{18}$ and has reported progress against the statement at the ensuing 2019 Conference, highlighting ongoing support. 
The WHO Framework Convention on Tobacco Control's (FCTC) explicit recognition of the disproportionate harm caused by commercial tobacco to Indigenous peoples

Indigenous peoples played key roles in the country delegations as part of the Intergovernmental Negotiating Body, the Framework Convention Alliance, to help incorporate text at the fourth session of the Intergovernmental Negotiating Body (INB4), reflecting the importance of commercial tobacco control in Indigenous contexts. ${ }^{19}{ }^{20}$ As a result, the FCTC preamble and guiding principles state that Parties are 'Deeply concerned about the high levels of smoking and other forms of tobacco consumption by [I]ndigenous peoples' (FCTC, Preamble, p2) ) $^{19}$ and '... the need to take measures to promote the participation of [I] ndigenous individuals and communities in the development, implementation and evaluation of tobacco control programmes that are socially and culturally appropriate to their needs and perspectives' (p6). ${ }^{19}$ Further, sovereign Indigenous nations can ratify the FCTC, including nations across Turtle Island, acknowledging that the USA is not an FCTC Party. In 2006, the first and only WHO Indigenous Peoples Forum on Tobacco Use in Aotearoa New Zealand occurred, with calls for the forum to be reinstated. ${ }^{18}$

\section{Indigenous commercial tobacco control leadership and governance}

This inherent leadership is becoming increasingly visible in the broader tobacco control community. For example, Māori leadership in Aotearoa New Zealand played an important role in introducing endgames to the tobacco control discourse. ${ }^{21-24}$ This included but is not limited to the introduction of a private members' bill to end tobacco sales, ${ }^{21}$ development of the Tupeka Kore ('No tobacco') concept for Aotearoa New Zealand, ${ }^{22-24}$ and recommendations from the Māori Affairs Select Committee Inquiry in $2010^{25}$ culminating in the commitment to achieving an essentially Smokefree Aotearoa by 2025 . The New Zealand Government's recently comprehensive and ambitious Proposals for a Smokefree Aotearoa 2025 Action Plan includes provisions for embedding Indigenous leadership and strengthening 'Māori governance of the tobacco control programme' (p11). ${ }^{26}$ We have also witnessed Indigenous governing roles embedded in commercial tobacco and nicotine society board structures, such as Society for Research on Nicotine and Tobacco (SRNT) Oceania, which includes identified positions, and we now have our first Indigenous president-elect (PNH, Navajo Nation (Diné)) of the SRNT, which is a USA-based international organisation. ${ }^{27}$

\section{Indigenous commercial tobacco control programmes}

The first national Indigenous commercial tobacco control programme was rolled out across Australia in 2010, the Regional Tackling Smoking and Healthy Lifestyle (now the Tackling Indigenous Smoking) programme. The first national Indigenous Australian (Aboriginal and Torres Strait Islander) antismoking mass media campaign, 'Break the Chain' (2010), was followed by 'Don't make smokes your story' in 2016. ${ }^{28}$ On Turtle Island, the Centers for Disease Control and Prevention Tips from Former Smokers mass media campaign included native participants, and the National Native Network was funded in 2014 to reduce commercial tobacco use and promote the roles of traditional tobacco and other traditional medicines. ${ }^{29}$ Communities across Turtle Island continue to advance commercial tobacco control, ${ }^{30-35}$ and many have dedicated and distributed Master Settlement Agreement funds to tribal nations to strengthen commercial tobacco control programmes through media campaigns, policy development and tobacco cessation support. ${ }^{30-33}$ In addition, a national American Indian Commercial Tobacco Program has been developed to provide phone and online commercial tobacco cessation support specifically for Indigenous people. ${ }^{36}$

\section{Tobacco-free Pacific 2025}

This network was launched in 2014 and the Pacific NonCommunicable Disease (NCD) Roadmap was endorsed. As commercial tobacco use continues to drive NCDs, it is encouraging to see our ongoing leadership to drive tax increases on tobacco in at least 16 Pacific Island countries since the roadmap was endorsed. ${ }^{37}$

Today, when we searched Tobacco Control for 'Indigenous', we received 171 results. The journal also recognises our affiliations as Indigenous peoples first, before our academic affiliations. ${ }^{3}$ We see increasing Indigenous authorship and encouraging trends in meaningful Indigenous engagement, including Indigenous-led research. This could reflect increased Indigenous research capacity, a trend that should be supported by increasing recruitment and training of Indigenous peoples, as well as seats at key tobacco control decision-making tables. ${ }^{38} 39$ There are increasing commitments within the tobacco control and health research community to comply with guidelines for core principles and values on the ethical conduct of research involving Indigenous peoples and the need for Indigenous leadership in tobacco control, as opposed to programmes and policies imposed on Indigenous peoples. This includes ethical guidelines across Australia, ${ }^{40}$ Turtle Island, ${ }^{41}$ Aotearoa New Zealand, ${ }^{42}$ the SRNT-Oceania Acknowledgement of Ethical Principles, ${ }^{27}$ Indigenous Data Sovereignty Principles, ${ }^{43-45}$ and the United Nations Declaration on the Rights of Indigenous Peoples-our rights to health, Indigenous sciences and our medicines, among others. ${ }^{46}$

Indigenous representation on tobacco control journal editorial boards, including Tobacco Control and Nicotine \& Tobacco Research, has continued to grow. And we see journals increasingly move towards 'Indigenous' as opposed to 'indigenous' ${ }^{3} 4748$; the act of capitalisation changes the narrative from a descriptive phrase to a proper noun. While these shifts may appear insignificant, they help to foster a safer environment for Indigenous peoples to reduce commercial tobacco use. This includes decolonising tobacco control, applying Indigenous worldviews on wise practices, and sharing Indigenous knowledges and mentorship opportunities in an environment where Indigenous peoples can flourish ${ }^{3143844}$ : shifting towards resiliency and strength rather than a model of 'risk', 'vulnerability' and 'disadvantage'. ${ }^{49}$

\section{CHALLENGES AND OPPORTUNITIES}

While we have taken a strength-based approach and challenged the deficit-based narratives actively placed on Indigenous peoples by highlighting successes and examples of Indigenous excellence, this does not mean skipping over the challenges. The magnitude of commercial tobacco use among Indigenous peoples is an international public health crisis, with disproportionately detrimental impacts on the health, economic and cultural well-being of Indigenous peoples. ${ }^{1}{ }^{19} 50$ Across Turtle Island we frequently see isolated pockets of Indigenous excellence in communities. $^{30-35}$ Consistent with the narrative that colonisation manufactures, these are generally silenced or not well documented in mainstream academic literature, or celebrated by the tobacco control community. This is partly reflected in the current development of an Indigenous Circle at the SRNT to create a safer space for Indigenous commercial tobacco control and as a means 
of addressing limited documentation of Indigenous excellence, nearly 30 years after the society was established on Turtle Island. Despite colonisation eroding, minimising, devaluing and limiting the ability to share Indigenous ways of knowing, being and doing, and in spite of ongoing targeting by the tobacco industry and their affiliates, Indigenous peoples continue to thrive. ${ }^{3} 1747$

In recent times, we have increasingly generated Indigenousspecific evidence driven by Indigenous peoples. In Australia, Aboriginal and Torres Strait Islander specific evidence indicated that the tobacco epidemic is at stage 3 of the Lopez model and has a number of unique characteristics, ${ }^{51}$ including high prevalence among men and women and variation by urban, regional and remote residence. ${ }^{51}$ Further, Indigenous-specific evidence indicated that smoking causes $37 \%$ of all Aboriginal and Torres Strait Islander peoples' deaths, ${ }^{50}$ almost twice the previous estimates. ${ }^{50}$ Consequently, there is even greater potential to improve Indigenous health outcomes by reducing commercial tobacco use. $^{50}$

Working together as Indigenous peoples with the support of, and in collaboration with, our non-Indigenous allies, governments and non-government organisations, we have a stronger and more focused means of improving Indigenous health outcomes and countering the tobacco industry's activities. There are opportunities to learn from each other around the world. ${ }^{19}$ The recent Euro-Western development of commercial tobacco control, which can support Indigenous knowledges and practices, including relationships with the tobacco plant since time immemorial, suggests that even more can be done to accelerate declines in commercial tobacco use.

\section{WHERE TO NEXT? 'THE DOLPHINS WILL ALWAYS TAKE US HOME'}

Fostering safe and ethical space for Indigenous commercial tobacco control research, science and practice is essential, including meeting the FCTC obligations in relation to Indigenous peoples. The Indigenous Peoples Tobacco Forum should be reinstated, in addition to other mechanisms, to help foster safer spaces for Indigenous commercial tobacco control, including Indigenous peoples to publish and share resources, learnings and successes. ${ }^{50}$ It is important to support and grow the FCTC, which recognises the disproportionate harm of commercial tobacco and the need to engage with Indigenous peoples in planning, delivering and evaluating comprehensive tobacco control free from vested interests. ${ }^{19}$ It also recognises Indigenous rights and the importance of sovereignty and self-determination in driving commercial tobacco control on their terms, ${ }^{46}$ and could include sovereign Indigenous nations ratifying the FCTC. Reflecting over the last 30 years provides a robust, evidencebased launching pad to rapidly accelerate declines in commercial tobacco prevalence and associated health harms. Empowering Indigenous peoples allows us to address emerging issues and be free of commercial tobacco on our own terms.

\section{Author affiliations}

Modewa Clan, Milne Bay, Papua New Guinea

${ }^{2}$ Aboriginal and Torres Strait Islander Health Group, National Centre for Epidemiology and Public Health, Australian National University, Canberra, Australian Capital Territory, Australia

${ }^{3}$ Wiradjuri, New South Wales, New South Wales, Australia

${ }^{4}$ School of Health and Medicine, Hunter Medical Research Institute, The University of Newcastle, Callaghan, New South Wales, Australia

${ }^{5} \mathrm{Ngāati} \mathrm{Hine/Ngāpuhi,} \mathrm{Aotearoa,} \mathrm{New} \mathrm{Zealand}$

${ }^{6}$ Eru Pomare Māori Health Research Unit, University of Otago, Wellington, New Zealand

${ }^{7} \mathrm{Ngā}$ ti Hauiti, Aotearoa, New Zealand
${ }^{8}$ Research for Māori Health and Development, Whakauae Research Services, Whanganui, New Zealand

${ }^{9}$ Samoa/Ngāti Tapuniu, Samoa, Samoa

${ }^{10}$ AUT Pacific Health Research Centre, Auckland University of Technology, Auckland, New Zealand

${ }^{11}$ Navajo Nation (Diné), Turtle Island, Arizona, USA

${ }^{12}$ Black Hills Center for American Indian Health, Rapid City, South Dakota, USA

${ }^{13}$ Cherokee Nation Citizen, Tahlequah, Oklahoma, USA

${ }^{14}$ Department of Biostatistics and Epidemiology, Hudson College of Public Health, The University of Oklahoma Health Sciences Center, Oklahoma City, Oklahoma, USA

${ }^{15} \mathrm{Ngāi}$ Tāmanuhiri, Rongowhakaata, Ngāti Kahungunu, Aotearoa, New Zealand

${ }^{16}$ Elder from the Kungarakan tribal group and a member of the Iwaidja tribal group, Northern Territory, Australia

${ }^{17}$ Office of the National Coordinator, Tackling Indigenous Smoking, Canberra, Australian Capital Territory, Australia

\section{Twitter Raglan Maddox @RaglanMaddox}

Contributors RM led the conceptualisation with all authors. RM led the preparation and all authors provided significant input and feedback, including through two round-table meetings via Zoom to reach consensus. All authors were involved in review, editing, proofing and approval of the manuscript.

Funding The authors have not declared a specific grant for this research from any funding agency in the public, commercial or not-for-profit sectors.

Competing interests None declared.

Patient consent for publication Not required.

Provenance and peer review Commissioned; externally peer reviewed.

\section{ORCID iDs}

Raglan Maddox http://orcid.org/0000-0002-2770-0686

Andrew Waa http://orcid.org/0000-0002-8078-0283

Heather Gifford http://orcid.org/0000-0003-2874-4434

El-Shadan Tautolo http://orcid.org/0000-0001-8444-6410

Patricia Nez Henderson http://orcid.org/0000-0002-8087-9929

\section{REFERENCES}

1 Colonna E, Maddox R, Cohen R. Review of tobacco use among aboriginal and torres strait Islander peoples, 2020. https://healthbulletin.org.au/wp-content/uploads/2020/ 06/AOD-Review-of-tobacco_Interactive-WEB_FINAL.pdf

2 Maddox R, Waa A, Lee K, et al. Commercial tobacco and indigenous peoples: a stock take on framework convention on tobacco control progress. Tob Control 2019;28:574-81.

3 Waa A, Robson B, Gifford $\mathrm{H}$, et al. Foundation for a smoke-free world and healthy Indigenous futures: an oxymoron? Tob Control 2020;29:237-40.

4 Truth reconciliation Commission of Canada. Truth and reconciliation Commission of Canada: house of commons, 2015. Available: https://en.wikipedia.org/wiki/Truth_ and_Reconciliation_Commission_of_Canada

5 Thurber KA, Colonna $E$, Jones $R$, et al. Prevalence of everyday discrimination and relation with wellbeing among Aboriginal and Torres Strait Islander adults in Australia. Int J Environ Res Public Health 2021;18. doi:10.3390/ijerph18126577. [Epub ahead of print: 1806 2021].

6 Alderete E, Erickson PI, Kaplan CP, et al. Ceremonial tobacco use in the Andes: implications for smoking prevention among Indigenous youth. Anthropol Med 2010;17:27-39.

7 Marshall M. Drinking smoke. University of Hawaii Press, 2013.

8 Ivers RG. Tobacco addiction and the process of colonisation. Aust N Z J Public Health 2002;26:280-1.

9 Nez Henderson P, Lee JP, Soto C, et al. Decolonization of tobacco in Indigenous communities of turtle island (North America). Nicotine Tob Res 2021. doi:10.1093/ntr/ ntab180. [Epub ahead of print: 13 Sep 2021].

10 Wilson J, Sabo S, Chief C, et al. Diné (Navajo) healer perspectives on commercial tobacco use in Ceremonial settings: an oral story project to promote smoke-free life. Am Indian Alsk Native Ment Health Res 2019;26:63-78.

11 Morton Ninomiya ME, Hurley N, Penashue J. A decolonizing method of inquiry: using institutional ethnography to facilitate community-based research and knowledge translation. Crit Public Health 2020;30:220-31.

12 Pearson JL, Waa A, Siddiqi K, et al. Naming racism, not race, as a determinant of tobacco-related health disparities. Nicotine Tob Res 2021;23:885-7.

13 Fforde C, Bamblett L, Lovett R, et al. Discourse, deficit and identity: Aboriginality, the race paradigm and the language of representation in contemporary Australia. Media International Australia 2013;149:162-73.

14 Boudreau G, Hernandez C, Hoffer D, et al. Why the world will never be tobacco-free: reframing "tobacco control" into a traditional tobacco movement. Am J Public Health 2016;106:1188-95. 
15 Human rights and equal opportunity Commission. Social justice report 2005 : Home, 2005. Available: https://humanrights.gov.au/our-work/aboriginal-and-torres-straitislander-social-justice/publications/social-justice-report-5

16 Commonwealth of Australia. Bringing them home national inquiry into the separation of Aboriginal and Torres Strait Islander children from their families. Sydney, NSW, 1997.

17 D'Silva J, O'Gara E, Villaluz NT, D'Silva J, O'Gara E. Tobacco industry misappropriation of American Indian culture and traditional tobacco. Tob Control 2018:27:e57-64.

18 Oceania Tobacco Control. Indigenous peoples to the 2017 Oceania tobacco control: smoke free Oceania. Indigenous peoples to the 2017 Oceania Tobacco Control Conference, 2017

19 World Health Organization. Framework convention on tobacco control: who regional office for south-east Asia, 2004. Available: https://apps.who.int/iris/handle/10665/ 206081

20 Action on smoking and health. in memoriam of Dr. Caleb Otto 2021. [Epub ahead of print: Available from] https://ash.org/memoriam-caleb-otto/

21 Thomson A. Ban smoking anywhere, any time, says Maori Party, 2006. Available: https://www.nzherald.co.nz/nz/ban-smoking-anywhere-any-time-says-maori-party/ 2HCRA5IWQHIAUYD4DSBM45JZ6A/

22 Gifford H, Bradbrook SK. Recent actions by Māori politicians and health Advocates for a tobacco-free Aotearoa/New Zealand, a brief review (occasional paper 2009/1), 2009. Occasional paper. Available: https://www.otago.ac.nz/wellington/otago022879. pdf

23 Waa A, Gifford H. A smokefree aotearoa action plan: why this could eliminate smoking disparities for Māori. Public Health Expert 2021 https://blogs.otago.ac. nz/pubhealthexpert/a-smokefree-aotearoa-action-plan-why-this-could-eliminatesmoking-disparities-for-maori/

24 .'Challenges: beyond Auahi Kore'. Aoteroa/New Zealand. Smokefree/Auahi Kore Conference, Wellington, Aotearoa New Zealand, 2006.

25 Māori Affairs Committee. Inquiry into the tobacco industry in Aotearoa and the consequences of tobacco use for Māori. Wellington: New Zealand Parliament, 2010.

26 Ministry of Health. Proposals for a Smokefree Aotearoa 2025 action plan: discussion document. Wellington Ministry of Health; 2021.

27 Society for Research in Nicotine \& Tobacco. Society for research in nicotine \& tobacco oceania about us, 2021. Available: https://www.srnt.org/page/srnt-o

28 Thomas D, Calma T. Tackling Indigenous smoking: a good news story in Australian tobacco control. Public Health Res Pract 2020:30:e3032019.

29 National Native Network. National native network (NNN) At-A-Glance, 2020: a project of the ITC of MI, GPTLHB, CRIHB, and SEARHC, 2020. Available: https:// keepitsacred.itcmi.org/wp-content/uploads/sites/5/2021/06/ITCM-Project-Briefs_ NNN-6.16.2021.pdf

30 Martinez SA, Beebe LA, Campbell JE. Oklahoma tobacco Helpline utilization and cessation among American Indians. Am J Prev Med 2015:48:S47-53.

31 Oklahoma State Department of Health Tobacco Use Prevention Service. Talking circles: a guide to tribal health disparities, 2021. Available: https://www.cdc.gov/tobacco/ tobacco_control_programs/surveillance_evaluation/success-stories/pdfs/oklahoma.pdf

32 Schillo BA, D'Silva J. ClearWay Minnesota's research program investing in innovative tobacco control research to improve the health of Minnesotans. Am J Prev Med 2008;35:\$439-41.
33 California department of public health. California tribal grants to reduce tobaccorelated disparities, 2019. Available: https://tcfor.catcp.org/index.cfm?fuseaction= opportunities.view0pp\&oppID $=78$

34 Nez Henderson P, Roeseler A, Moor G, et al. Advancing smoke-free policy adoption on the Navajo nation. Tob Control 2016;25:i26-31.

35 O'Donald ER, Miller CP, O'Leary R, et al. Active smoking, secondhand smoke exposure and serum cotinine levels among Cheyenne river Sioux communities in context of a tribal public health policy. Tob Control 2020;29:570-6.

36 National Jewish Health. American Indian commercial tobacco program, 2021. Available: https://aiquitline.com/

37 Pacific health ministers meetings. PIC13/S4/1 Pacific noncommunicable diseases (Ncd) roadmap and monitoring alliance for Ncd action (manA): progress update, 2019. Available: https://www.who.int/docs/default-source/wpro---documents/ dps/phmm-phoh-documents/13th-phmm-outcome-document---en.pdf?sfvrsn= 68ab91d3_0

38 Lee K, Smith J, Thompson S. Engaging Indigenous peoples in research on commercial tobacco control: a scoping review. AlterNative: An International Journal of Indigenous Peoples 2020;16:332-55.

39 Chamberlain C, Perlen S, Brennan S, et al. Evidence for a comprehensive approach to Aboriginal tobacco control to maintain the decline in smoking: an overview of reviews among Indigenous peoples. Syst Rev 2017;6:135.

40 Aboriginal Health \& Medical Research Council. AH\&MRC ethical guidelines: key principles (2020) V2.0, 2020. Available: https://www.ahmrc.org.au/publication/ahmrcguidelines-for-research-into-aboriginal-health-2020/

41 First Nations Information Governance Centre. The first nations principles of OCAP®, 2021. Available: https://fnigc.ca/ocap-training/

42 Hudson M, Milne M, Reynolds P. Te Ara tika. guidelines for Māori research ethics a framework for researchers and ethics Committee members. 29, 2010. https://www. fmhs.auckland.ac.nz/assets/fmhs/faculty/tkhm/tumuaki/docs/teara.pdf

43 Mecredy G, Sutherland R, Jones C. First nations data governance, privacy, and the importance of the OCAP® principles. Int J Popul Data Sci 2018;3.

44 Lovett R, Lee V, Kukutai T. Good data practices for Indigenous data sovereignty and governance, 2019: 26-36. https://researchcommons.waikato.ac.nz/handle/10289/ 12919

45 Carroll SR, Herczog E, Hudson M, et al. Operationalizing the care and fair principles for Indigenous data futures. Sci Data 2021;8:1-6.

46 United Nations General Assembly. United nations declaration on the rights of Indigenous peoples, 2007. Available: https://www.un.org/development/desa/ indigenouspeoples/declaration-on-the-rights-of-indigenous-peoples.html

47 Waa A, Maddox R, Nez Henderson P. Big tobacco using Trojan horse tactics to exploit Indigenous peoples. Tob Control 2020;29:e132-3.

48 Canuto K, Finlay SM. I am not here for your convenience. Wiley Online Library, 2021.

49 Katz AS, Hardy B-J, Firestone M, et al. Vagueness, power and public health: use of 'vulnerable' in public health literature. Crit Public Health 2020;30:601-11.

50 Thurber KA, Banks E, Joshy G, et al. Tobacco smoking and mortality among Aboriginal and Torres Strait Islander adults in Australia. Int J Epidemiol 2021:50:942-54.

51 Lovett R, Thurber KA, Maddox R. The Aboriginal and Torres Strait Islander smoking epidemic: what stage are we at, and what does it mean? Public Health Res Pract 2017;27:e2741733. 